\title{
Short-term nitrous oxide emissions from pasture soil as influenced by urea level and soil nitrate
}

\author{
S.O. Petersen ${ }^{1,3}$, S. Stamatiadis ${ }^{2}$ \& C. Christofides ${ }^{2}$ \\ ${ }^{1}$ Danish Inst Agricultural Sciences, Department Agroecology, Research Centre Foulum, Denmark. ${ }^{2}$ GAIA \\ Environmental Research and Education Centre, Soil Ecology \& Biotechnology Laboratory, Kifissia, GR. \\ ${ }^{3}$ Corresponding author*
}

Received . Accepted in revised form

Key words: denitrifying enzyme activity (DEA), dissolved organic carbon, GC-IRMS, nitrous oxide, osmotic potential, potential ammonium oxidation (PAO), urea

\begin{abstract}
Nitrogen excreted by cattle during grazing is a significant source of atmospheric nitrous oxide $\left(\mathrm{N}_{2} \mathrm{O}\right)$. The regulation of $\mathrm{N}_{2} \mathrm{O}$ emissions is not well understood, but may vary with urine composition and soil conditions. This laboratory study was undertaken to describe short-term effects on $\mathrm{N}_{2} \mathrm{O}$ emissions and soil conditions, including microbial dynamics, of urea amendment at two different rates ( 22 and $43 \mathrm{~g} \mathrm{~N} \mathrm{~m}^{-2}$ ). The lower urea concentration was also combined with an elevated soil $\mathrm{NO}_{3}^{-}$concentration. Urea solutions labelled with 25 atom\% ${ }^{15} \mathrm{~N}$ were added to the surface of repacked pasture soil cores and incubated for 1, 3, 6 or 9 days under constant conditions (60\% WFPS, $\left.14{ }^{\circ} \mathrm{C}\right)$. Soil inorganic $\mathrm{N}\left(\mathrm{NH}_{4}^{+}, \mathrm{NO}_{2}^{-}\right.$and $\left.\mathrm{NO}_{3}^{-}\right), \mathrm{pH}$, electrical conductivity and dissolved organic $\mathrm{C}$ were quantified. Microbial dynamics were followed by measurements of $\mathrm{CO}_{2}$ evolution, by analyses of membrane lipid (PLFA) composition, and by measurement of potential ammonium oxidation and denitrifying enzyme activity. The total recovery of ${ }^{15} \mathrm{~N}$ averaged $84 \%$. Conversion of urea- $\mathrm{N}$ to $\mathrm{NO}_{3}^{-}$was evident, but nitrification was delayed at the highest urea concentration and was accompanied by an accumulation of $\mathrm{NO}_{2}^{-}$. Nitrous oxide emissions were also delayed at the highest urea amendment level, but accelerated towards the end of the study. The $\mathrm{pH}$ interacted with $\mathrm{NH}_{4}^{+}$to produce inhibitory concentrations of $\mathrm{NH}_{3}(\mathrm{aq})$ at the highest urea concentration, and there was evidence for transient negative effects of urea amendment on both nitrifying and denitrifying bacteria in this treatment. However, PLFA dynamics indicated that initial inhibitory effects were replaced by increased microbial activity and net growth. It is concluded that urea-N level has qualitative, as well as quantitative effects on soil $\mathrm{N}$ transformations in urine patches.
\end{abstract}

\section{Introduction}

For Western Europe it is estimated that, on average, $8 \%$ of total $\mathrm{N}$ excreted by dairy cattle is deposited on pastures (IPCC, 1997). Nitrogen intake and excretion is influenced by factors such as lactation stage, pasture quality (clover percentage, $\mathrm{N}$ concentration) and feed composition. Excess $\mathrm{N}$ is mainly excreted as urea in the urine, i.e., the proportion of urea-N increases with total urinary $\mathrm{N}$ concentration (Petersen

*FAX No: +45-8999-1619.

E-mail: soren.o.petersen@agrsci.dk et al., 1998). In pasture soil, urea is completely hydrolyzed within $24-48 \mathrm{~h}$, and subsequent transformations of $\mathrm{NH}_{4}^{+}$and $\mathrm{NO}_{3}^{-}$via nitrification and denitrification make urine patches a potentially important source of $\mathrm{N}_{2} \mathrm{O}$ (e.g., Clough et al., 1998; Monaghan and Barraclough, 1993; Yamulki et al., 1998).

The regulation of nitrification and denitrification in urine patches is not well understood, and $\mathrm{N}_{2} \mathrm{O}$ emissions may result from a combination of several factors, including elevated soil moisture, stresses caused by dissolved ammonia, $\mathrm{NH}_{3}(\mathrm{aq})$, and/or low osmotic potential, and elevated oxygen demand due to carbon leakage from scorched roots and possibly 
lysed microorganisms (Monaghan and Barraclough, 1992; Richards and Wolton, 1975; Stark and Firestone, 1995). If denitrification is restricted by $\mathrm{NO}_{3}^{-}$ availability, then overlapping urine patches with $\mathrm{NO}_{3}^{-}$ from a previous deposition could have elevated rates of $\mathrm{N}_{2} \mathrm{O}$ emission.

This laboratory study was conducted to investigate the short-term turnover of urea in pasture soil under typical summer grazing conditions. A wide range of variables were monitored for characterization of the physicochemical environment, $\mathrm{N}$ transformations and associated microbial dynamics in urine patches.

\section{Materials and methods}

Soil for the laboratory study was sampled in late May from an 8-yr old grazed pasture near Research Centre Foulum in Denmark (55 $52^{\prime} \mathrm{N}, 9^{\circ} 34^{\prime} \mathrm{E}$ ); the area sampled had not been grazed since the previous autumn. The sandy loam soil (Typic Hapludult) contained $2.7 \% \mathrm{C}$ and $0.18 \% \mathrm{~N}$, the $\mathrm{pH}\left(\mathrm{H}_{2} \mathrm{O}\right)$ was 6.3 , and total CEC was $87 \mathrm{cmol} \mathrm{kg}^{-1}$. Soil (0-20 cm depth) was sieved $(<4 \mathrm{~mm})$ to remove roots and stones. Gravimetric soil moisture was $15.2 \%$, or $80 \%$ of field capacity (FC). The soil was stored for a week at $4{ }^{\circ} \mathrm{C}$, and then at the incubation temperature $\left(14^{\circ} \mathrm{C}\right)$ for $24 \mathrm{~h}$ before initiation of the experiment.

\section{Experimental set-up}

In the experiment, solutions of urea labelled with 25 atom $\%{ }^{15} \mathrm{~N}$ were added to repacked soil cores at a rate of $4 \mathrm{~L} \mathrm{~m}^{-2}$. The treatments were: (i) $C T L\left(0 \mathrm{~g} \mathrm{~N} \mathrm{~L}^{-1}\right)$; (ii) $L U\left(5 \mathrm{~g}\right.$ urea- $\left.\mathrm{N} \mathrm{L}^{-1}\right)$; (iii) $H U\left(10 \mathrm{~g}\right.$ urea- $\left.\mathrm{N} \mathrm{L}^{-1}\right)$; (iv) $L U N\left(5 \mathrm{~g}\right.$ urea- $\left.\mathrm{N} \mathrm{L}^{-1}+50 \mu \mathrm{g} \mathrm{NO}_{3}^{-}-\mathrm{N} \mathrm{cm}^{-3}\right)$; and (v) $\mathrm{NO}_{3}^{-}$only $\left(50 \mu \mathrm{g} \mathrm{NO}_{3}^{-}-\mathrm{N} \mathrm{cm}^{-3}\right.$ ). Treatment (v) was only used for respiration measurements and final soil analyses.

One day before the experiment was initiated, soil portions of $100 \mathrm{~g}$ (dry wt. equivalent) were weighed out, and soil moisture adjusted to $46 \%$ water-filled pore space (WFPS) by drop-wise addition of distilled water or a $\mathrm{KNO}_{3}$ solution. Each sample was mixed, transferred to cylinders (internal diameter, $44 \mathrm{~mm}$ ), and packed to a bulk density of $1.2 \mathrm{~g} \mathrm{~cm}^{-3}$. Urea solutions or water was added dropwise to the appropriate cylinders, which were subsequently sealed at both ends with Parafilm that was perforated with a needle to facilitate gas exchange. All treatments were prepared in triplicate for each of four sampling times $(1,3,6$ and
$9 \mathrm{~d})$ and incubated at $14{ }^{\circ} \mathrm{C}$. The final moisture content of all treatments was $60 \%$ WFPS, and the two urea amendment levels corresponded to 22 and $43 \mathrm{~g} \mathrm{~N} \mathrm{~m}^{-2}$, respectively. The total of 51 samples, including three replicates with $\mathrm{NO}_{3}^{-}$only for the last sampling, were weighed at regular intervals during incubation; water loss was negligible $(\sim 0.2 \mathrm{~mL})$.

\section{Sampling}

Carbon dioxide and $\mathrm{N}_{2} \mathrm{O}$ evolution rates were determined after c. $0.2,0.5,1,3,6$ and 9 d. Three replicates from each treatment were randomly selected and transferred to $1 \mathrm{~L}$ gas tight containers equipped with a septum for gas sampling. Carbon dioxide was analyzed at to and again after $60 \mathrm{~min}$. At this time, $13 \mathrm{~mL}$ headspace gas was transferred to evacuated exetainers for isotope ratio mass spectrometry (IRMS) analysis of ${ }^{14+15} \mathrm{~N}_{2} \mathrm{O}$ and ${ }^{14+15} \mathrm{~N}_{2}$. At the four last samplings, the replicates used for gas flux measurements were then destructively sampled for determination of $\mathrm{pH}$, electrical conductivity (EC), dissolved organic carbon (DOC), inorganic and total N, and phospholipid fatty acid (PLFA) composition. Soil for total $\mathrm{N}$ determination was wetted with $\mathrm{NaH}_{2} \mathrm{PO}_{4}(0.5 M, \mathrm{pH}$ 4.3) to prevent $\mathrm{NH}_{3}$ volatilization during air-drying. On day 3, soil was also sub-sampled for determination of potential ammonium oxidation (PAO) and denitrifying enzyme activity (DEA). These assays were assumed to reflect the metabolic capacity for each process at the time of sampling.

\section{Analytical techniques}

Urea solutions were prepared from a 99 atom\% stock (Eurisotop, Saint Aubin, France) and unlabelled urea. Carbon dioxide was analyzed by a HP-P200 portable GC equipped with a thermal conductivity detector and a Poraplot $\mathrm{Q}$ column using $\mathrm{He}$ as a carrier gas. Nitrous oxide concentrations and ${ }^{15} \mathrm{~N}-\mathrm{N}_{2} \mathrm{O}$ were determined using a continuous flow triple collector isotope ratio mass spectrometer linked to a GC and with automated cryogenic pre-concentration (ANCA-TGII system, IRMS, PDZ Europa). The sample initially passed through a water and $\mathrm{CO}_{2}$ trap. Nitrous oxide was cryofocused before passing through a GC column (Poraplot Q, Chrompack) and through to the MS. Nitrogen was purged through a $5 \AA$ Molecular Sieve GC column (Chrompack) and then through to the MS. GC flows were optimized so that nitrous oxide was detected by the MS prior to nitrogen. Lab standards were calibrated against atmospheric $\mathrm{N}_{2}\left(\delta^{15} \mathrm{~N}=0\right)$ 
for $\delta^{15} \mathrm{~N}$. The lab standard used was $50 \mathrm{ppm} \mathrm{N}_{2} \mathrm{O}$ in $\mathrm{N}_{2}\left(\delta^{15} \mathrm{~N}-\mathrm{N}_{2} \mathrm{O}=-0.9872\right)$. Overall precision (machine error plus sample preparation error) for nitrogen isotopic composition was $0.37 \%$.

An automated combustion elemental analyzer interfaced with an IRMS (ANCA-SL system) was used to measure total nitrogen content as well as the nitrogen isotopic composition of soil samples (14 \pm $0.1 \mathrm{mg}$ ). Samples were prepared as described in Schepers et al. (1989). Sharpsburg silty clay loam $\left(\delta^{15} \mathrm{~N}=10.647 \%\right)$ was used as the soil working standard. Overall precision (machine error plus sample preparation error) for nitrogen isotopic composition was $0.3-1 \%$.

Ammonium and $\mathrm{NO}_{2}^{-}$were determined colorimetrically and $\mathrm{NO}_{3}^{-}$by ion chromatography (Keeney and Nelson, 1982). Isotopic composition of $\mathrm{NH}_{4}^{+}$and $\mathrm{NO}_{2}^{-}+\mathrm{NO}_{3}^{-}$was determined by IRMS after microdiffusion (Sørensen and Jensen, 1991). However, the results for ${ }^{15} \mathrm{~N}-\mathrm{NH}_{4}^{+}$were not reliable due to instrument overload and had to be estimated (see next section).

DOC was extracted in $0.5 \mathrm{M} \mathrm{K}_{2} \mathrm{SO}_{4}$ (Vance et al., 1987) and filtered extracts analyzed on an DC-180 Carbon Analyzer (Dohrmann, Xertex). pH and EC was measured in 1:1 soil:water mixtures (Smith and Doran, 1996). EC results were expressed as osmotic potentials using the expression:

$$
\psi_{\mathrm{o}}=-\mathrm{EC}_{\mathrm{e}}\left(\Theta_{\mathrm{s}} / \Theta\right) 0.036
$$

where $\mathrm{EC}_{\mathrm{e}}$ is the electrical conductivity of a saturated extract $\left(\mathrm{dS} \mathrm{m}{ }^{-1}\right), \Theta_{\mathrm{s}}$ and $\Theta$ are the volumetric water contents of the saturated extract and the fresh soil, respectively, and 0.036 is an empirical conversion factor $\left(\mathrm{MPa} \mathrm{dS}^{-1} \mathrm{~m}\right.$ ) (Rawlins and Campbell, 1986). In the present experiment, EC was strongly correlated with inorganic $\mathrm{N}\left(r^{2}=0.62, P<0.001\right)$.

PAO was determined according to Belser and Mays (1980), and DEA as described by Tiedje et al. (1989). Phospholipid fatty acid analyses followed Petersen et al. (2002). A total of 34 fatty acids were consistently observed in the pasture soil, although in this context only total concentrations and proportions of selected fatty acids related to physiological status will be presented.

\section{Isotope calculations}

The fractions of soil $\mathrm{N}$ pools derived from urea, $\mathrm{N}_{\mathrm{dfu}}$, were calculated according to a standard equation for fertilizer uptake studies (Nason and Myrold, 1991):

$$
\begin{aligned}
\mathrm{N}_{\mathrm{dfu}}= & {\left[{ }^{15} \mathrm{~N} \text { atom } \%, \text { fraction }-0.366\right] / } \\
& {\left[{ }^{15} \mathrm{~N} \text { atom } \%, \text { urea }-0.366\right] }
\end{aligned}
$$

However, labelling of $\mathrm{NH}_{4}^{+}$had to be estimated (possible for days 3, 6 and 9 only) on the basis of net changes in total $\mathrm{NO}_{3}^{-}$and ${ }^{15} \mathrm{NO}_{3}^{-}$concentrations during each time interval:

$$
\left[{ }^{15} \mathrm{NH}_{4}^{+}\right]_{\mathrm{t} 2}=\left(\Delta_{\mathrm{t} 1, \mathrm{t} 2}\left[{ }^{15} \mathrm{NO}_{3}^{-}\right]\right) /\left(\Delta_{\mathrm{t} 1, \mathrm{t} 2}\left[{ }^{14+15} \mathrm{NO}_{3}^{-}\right]\right) \text {. }
$$

Equation 3 assumes that labelling of the $\mathrm{NO}_{3}^{-}$produced corresponded to the labelling of the substrate pool, and that there was no turnover of the $\mathrm{NO}_{3}^{-}$pool.

The ${ }^{15} \mathrm{~N}$ content of $\mathrm{N}_{2} \mathrm{O}$ emitted was calculated by subtracting the background in air $\left(310 \mathrm{ppm} \mathrm{N} \mathrm{N}_{2} \mathrm{O}\right.$ with 0.366 atom $\%{ }^{15} \mathrm{~N}$ ). Accumulated emissions of $\mathrm{N}_{2} \mathrm{O}$ were estimated assuming linear rate changes between samplings, and the fraction of $\mathrm{N}_{2} \mathrm{O}$ derived from urea at each sampling was calculated using Eq. 2.

\section{Statistical analyses}

Treatment effects and temporal dynamics were analyzed by a linear mixed model, and using a Tukey multiple comparisons test to identify differences.

\section{Results}

\section{Inorganic $N$ dynamics}

Pools of $\mathrm{NH}_{4}^{+}$and $\mathrm{NO}_{3}^{-}$in the soil solution of treatments $C T L, L U, H U$ and $L U N$ are shown in Figure 1 (note different scale for $C T L$ ). The higher background of $\mathrm{NO}_{3}^{-}$in $L U N$ was evident, as was the accumulation of $\mathrm{NO}_{3}^{-}$over time in all treatments with urea amendment.

Figure 2 shows $\mathrm{NO}_{2}^{-}$concentrations, which were initially negligible. In $L U$ and $L U N$ a transient, but non-significant accumulation of $\mathrm{NO}_{2}^{-}$was observed during the $9-\mathrm{d}$ period $(P>0.1)$. The pattern in $H U$ was very different, with a significant $(P<0.0001)$ accumulation of $\mathrm{NO}_{2}^{-}$between 3 and 9 days.

Based on the IRMS analyses, the average recovery of urea-N in the soil $\mathrm{N}$ was determined to be $84 \pm 1.1 \%$ (mean \pm standard error). The $\mathrm{N}$ balances for day 3, 6 and 9 are shown in Figure 3. Nitrate accumulation was delayed in $H U$ compared to $L U$ and $L U N$. 

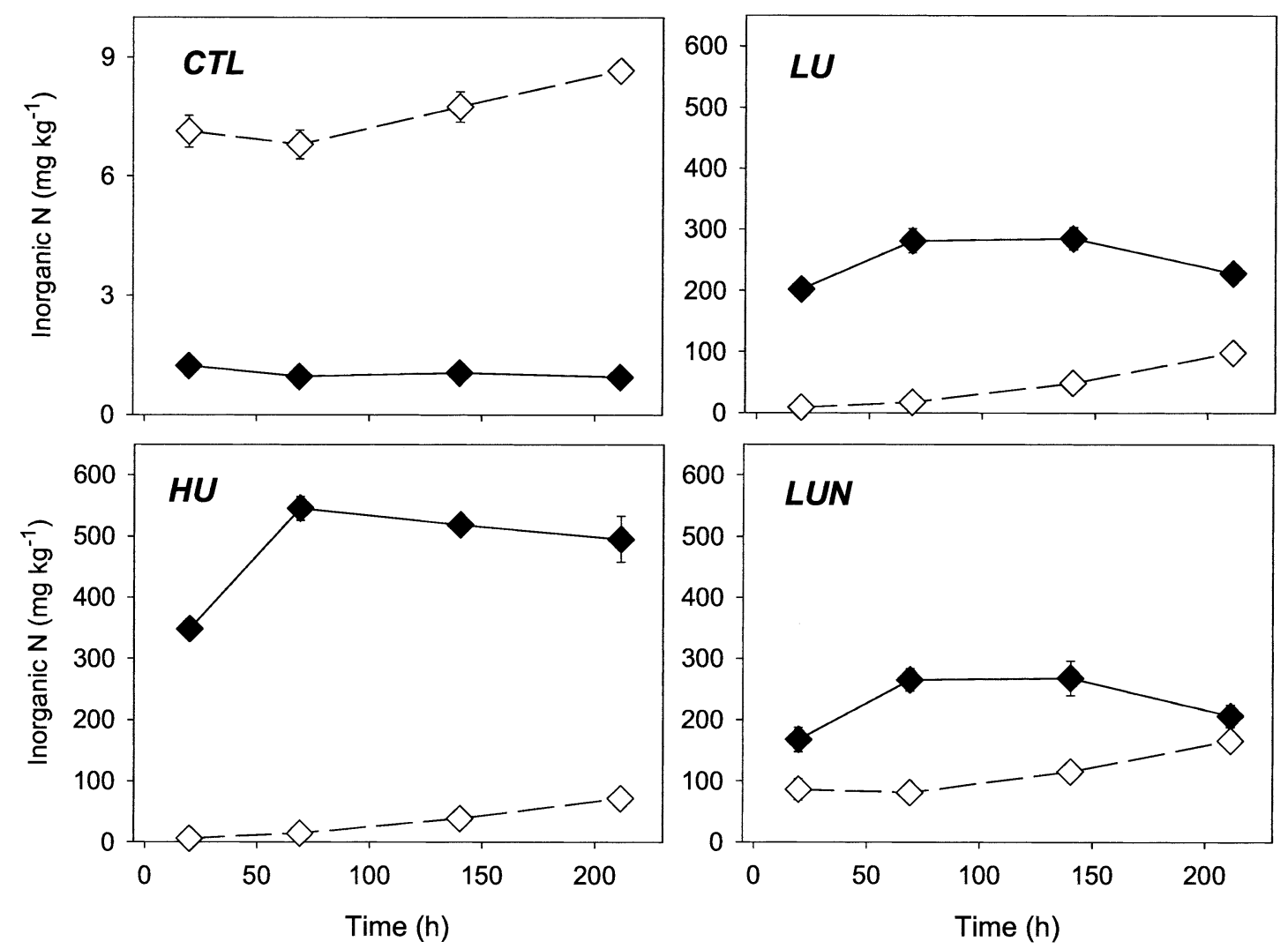

Figure 1. Concentrations of $\mathrm{NH}_{4}^{+}(\diamond)$ and $\mathrm{NO}_{3}^{-}(\diamond)$ in the treatments indicated. Error bars represent standard error $(n=3)$.

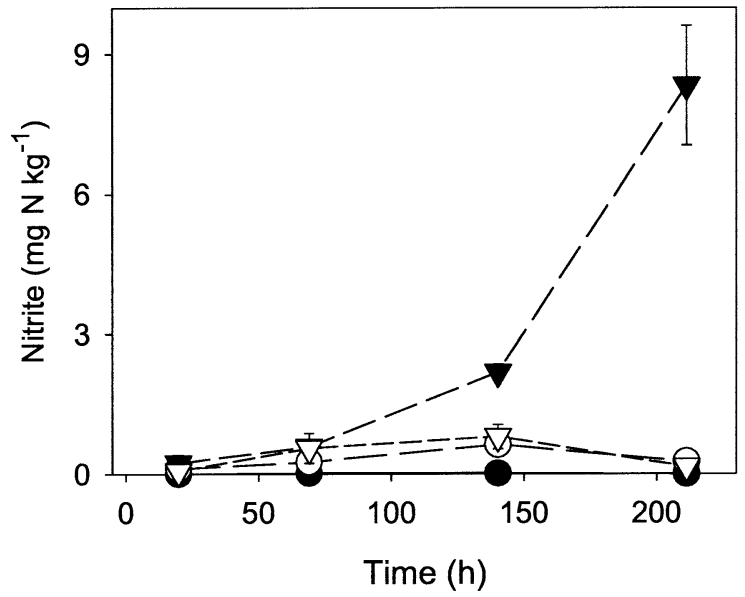

Figure 2. Concentrations of $\mathrm{NO}_{2}^{-}$in $C T L(\bullet), L U(\circ), H U(\mathbf{\nabla})$ and $\operatorname{LUN}(\nabla)$ during the 9 -d experiment. Error bars represent standard error $(n=3)$.

\section{$\mathrm{N}_{2} \mathrm{O}$ emissions}

In Figure $4, \mathrm{~N}_{2} \mathrm{O}$ production rates are shown on an area basis. Emission rates from $L U$ increased until day 6, while emission rates from $L U N$ levelled off after day 3. Nitrous oxide emission, like nitrification, was delayed in $H U$ during the first 6 days, but then increased dramatically.

The sources of $\mathrm{N}_{2} \mathrm{O}$ on each sampling day are shown in Table 1. The amendment of $\mathrm{NO}_{3}^{-}$alone (treatment $N$ ) did not stimulate $\mathrm{N}_{2} \mathrm{O}$ production in the soil. The treatments $L U, H U$ and $L U N$ stimulated the emission of soil-derived $\mathrm{N}_{2} \mathrm{O}$ similarly. With respect to $\mathrm{N}_{2} \mathrm{O}$ derived from urea the picture was more complex, reflecting that emissions from $L U$ were higher than from $L U N$ throughout the experiment, whereas in $H U$ the emissions of $\mathrm{N}_{2} \mathrm{O}$ derived from urea were initially depressed, but greatly increased between day 6 and 9 (data not shown).

\section{Soil solution composition}

Soil pH (Figure 5A) was immediately raised by urea amendment, though with different effects of the three treatments $(P<0.0001)$. In all treatments with urea, $\mathrm{pH}$ declined continuously during the experiment $(P<$ $0.05)$. EC levels in $L U, H U$ and $L U N$ initially corres- 
Table 1. Accumulated emissions of $\mathrm{N}_{2} \mathrm{O}$ derived from urea and soil, as well as accumulated rates of $\mathrm{CO}_{2}$ evolution, after 9 days. The treatments were: $C T L$, water amendment; $L U, 22 \mathrm{~g}$ urea-N m${ }^{-2} ; H U, 43 \mathrm{~g}$ urea-N m${ }^{-2} ; L U N, 22 \mathrm{~g}$ urea- $\mathrm{N} \mathrm{m}^{-2}+50 \mu \mathrm{g} \mathrm{NO}_{3}^{-} \mathrm{N} \mathrm{cm}^{-3} ; \mathrm{N}, 50 \mu \mathrm{g} \mathrm{NO}_{3}^{-} \mathrm{N} \mathrm{cm}^{-3}$. The $\mathrm{CO}_{2}$ data were corrected for urea-derived $\mathrm{CO}_{2}$ by assuming that urea was completely hydrolyzed and urea-C released to the atmosphere. Letters indicate significant $(P<0.05)$ differences within each column $(n=3)$

\begin{tabular}{lccc}
\hline & $\mathrm{N}_{2} \mathrm{O}$ from urea & \multicolumn{2}{c}{$\mathrm{N}_{2} \mathrm{O}$ from soil } \\
$\mathrm{mg} \mathrm{N}$ & $\begin{array}{l}\mathrm{CO}_{2}, \text { corrected } \\
\mathrm{mg} \mathrm{C}\end{array}$ \\
\hline$C T L$ & $0.3 \mathrm{c}$ & $15.9 \mathrm{c}$ & $8.2 \mathrm{c}$ \\
$L U$ & $27.6 \mathrm{a}$ & $26.2 \mathrm{a}$ & $19.0 \mathrm{~b}$ \\
$H U$ & $22.8 \mathrm{ab}$ & $22.0 \mathrm{a}$ & $36.4 \mathrm{a}$ \\
$L U N$ & $15.2 \mathrm{~b}$ & $24.7 \mathrm{ab}$ & $6.8 \mathrm{c}$ \\
$N$ & $0.4 \mathrm{c}$ & $17.2 \mathrm{bc}$ & $8.4 \mathrm{c}$ \\
\hline
\end{tabular}

ponded to osmotic potentials of -0.05 to $-0.12 \mathrm{MPa}$ after $1 \mathrm{~d}$, decreasing to -0.14 to $-0.19 \mathrm{MPa}$ after $9 \mathrm{~d}$ (Figure 5B).

Relative to CTL, concentrations of DOC (Figure 6A) were elevated in urea amended soil after 1 and 3 days, and in $H U$ and $L U N$ throughout the experiment $(P<0.05)$. In $H U$, DOC decreased between day 1 and day 3 , and then increased again to the original level $(P<0.01)$. $L U$ showed a small, but significant $(P<0.05)$ decrease in DOC during the experiment.

\section{Soil respiration}

Soil $\mathrm{CO}_{2}$ evolution from urea and soil respiration are shown in Figure 6B; the production was corrected for dissolved $\mathrm{CO}_{2}$ and carbonates (Lindsay, 1979). Effects of all treatments had ceased by the end of the 9-d period, despite the differences in DOC availability. $\mathrm{CO}_{2}$ evolution from $L U N$ was always lower than from $L U$. In Table 1, the accumulated release of $\mathrm{CO}_{2}$ from each treatment is shown.

\section{Microbial dynamics}

Potential ammonium oxidation (PAO) and denitrifying enzyme activity (DEA) were quantified after $3 \mathrm{~d}$ (Figure 7A). The buffered PAO assay ( $\mathrm{pH} 7.4)$ was stimulated in $L U, H U$ and $L U N$ relative to $C T L(P<$ $0.05)$. The DEA assay indicated a reduction in the potential for denitrification in both $L U, H U$ and $L U N$ $(P<0.05)$. The decrease appeared to be stronger in the $H U$ treatment, but differences between $L U, H U$ and $L U N$ were not significant $(P=0.10-0.15)$. The
DEA assay is not buffered, and $\mathrm{pH}$ of the slurries were $6.3(C T L), 6.9(L U$ and $L U N)$ and $7.2(H U)$, whereas the $\mathrm{pH}$ of the undisturbed soil was 6.4 ; all pair-wise differences were significant at $P<0.01$, as determined by Tukey's multiple comparisons test.

Figure 7B presents concentrations of membrane lipid fatty acids (PLFA). Initial levels of PLFA in $H U$ and $L U N$ were elevated relative to $C T L(P<0.01)$. The levels of PLFA in $L U$ and $L U N$ remained constant throughout the experiment. In the $H U$ treatment, the apparent decrease between 1 and 3 days was not significant $(P>0.1)$. Between day 3 and day 9, PLFA concentrations in $H U$ increased by $25 \%(P=0.02)$.

Figure 8 shows ratios of selected PLFA's which have been linked with the physiological status of microorganisms. These included the ratios between the cyclopropane fatty acids cy 17:0 and cy 19:0 and their metabolic precursors, palmitoleic acid $(16: 1 \omega 7 \mathrm{c})$ and cis-vaccenic acid $(18: 1 \omega 7 \mathrm{c})$, as well as the trans-cis ratio of 16:1 $\omega 7$. Both cyclopropane/precursur ratios remained constant in $C T L$ and $L U N$ during the experiment, whereas the cy 17:0/16:1 $\omega 7 \mathrm{c}$ ratio of $L U$ and

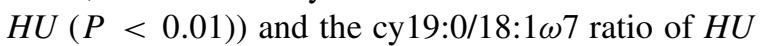
$(P=0.0003)$ decreased. Ratios of $16: 1 \omega 7 \mathrm{t} / \mathrm{c}$ decreased significantly $(P<0.05)$ in the treatments $L U$ and $H U$ during the experiment. All significant changes occurred mainly between day 3 and day 9 .

\section{Discussion}

This incubation experiment aimed to describe the relationship between urea turnover and $\mathrm{N}_{2} \mathrm{O}$ emissions 

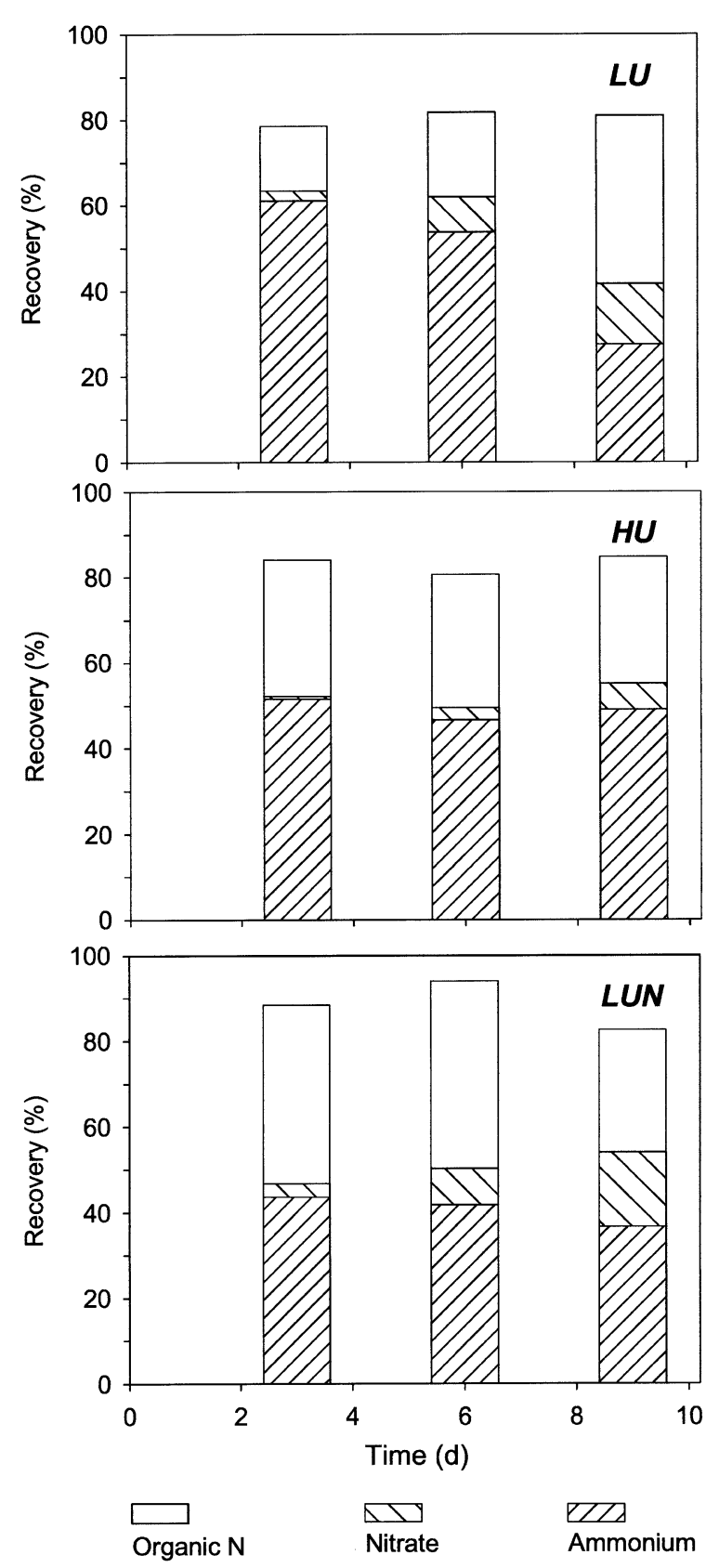

Figure 3. Total recovery of ${ }^{15} \mathrm{~N}$ added in urea as soil $\mathrm{N}$, as $\mathrm{NH}_{4}^{+}$ and as $\mathrm{NO}_{3}^{-}\left(\mathrm{N}_{2} \mathrm{O}\right.$ emissions were insignificant).

in a pasture soil, and the possible interaction with $\mathrm{NO}_{3}^{-}$availability. The moisture content during incubation was kept at $60 \%$ WFPS where denitrification was not expected to occur unless stimulated by urea transformations. For nitrification, this moisture level was probably near optimal (Doran et al., 1988). Urea alone was added rather than artificial cattle urine, since

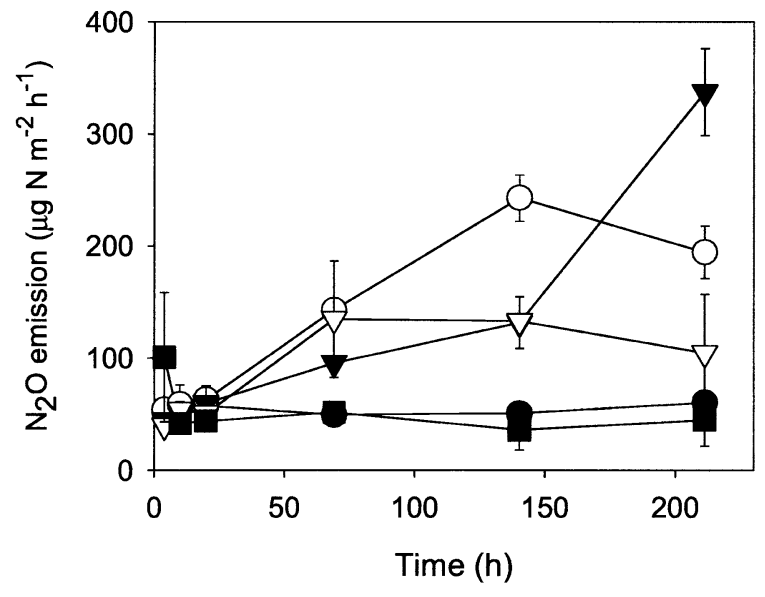

Figure 4. Nitrous oxide emission rates $\left(\mu \mathrm{g} \mathrm{m}^{-2} \mathrm{~h}^{-1}\right)$ in the $C T L$ $(\bullet), L U(\circ), H U(\boldsymbol{\nabla}), L U N(\nabla)$ and $N\left(\mathrm{NO}_{3}^{-}\right.$only) (ם). Bars represent standard errors $(n=3)$.

we wanted to avoid the interference from turnover of organic constituents in the urine (Bristow et al., 1992). The absence of hippuric acid probably delayed urea hydrolysis in the soil (Whitehead et al., 1989), thereby dampening the initial increase in $\mathrm{pH}$ (Sherlock and Goh, 1984; Somda et al., 1997), as well as the osmotic down-shock. Thus, it is likely that any stresses imposed on soil organisms would be as great or greater in a pasture after deposition of cattle urine.

Concentrations of urea-N applied to the soil surface, 5 and $10 \mathrm{~g} \mathrm{~N} \mathrm{~L}^{-1}$, were selected on the basis of previous analyses of urine from cattle in this grazing system (Petersen et al., 1998). The input to the soil corresponded to 22 and $43 \mathrm{~g} \mathrm{~N} \mathrm{~m}^{-2}$, which is within the range of 20 to $80 \mathrm{~g} \mathrm{~N} \mathrm{~m}^{-2}$ quoted by Oenema et al. (1997) as typical for urine patches.

The use of ${ }^{15} \mathrm{~N}$-labelled urea made it possible to follow the turnover of the $\mathrm{N}$ introduced to the soil. For day 1 , reliable data on ${ }^{15} \mathrm{NH}_{4}^{+}$and ${ }^{15} \mathrm{NO}_{3}^{-}$could not be obtained, but for subsequent sampling days the recovery of urea- $\mathrm{N}$ in mineral $\mathrm{N}$ and $\mathrm{N}_{2} \mathrm{O}$ was mostly between 40 and $65 \%$, and total ${ }^{15} \mathrm{~N}$ recovery averaged $84 \%$. The missing urea-N was presumably lost to the atmosphere as $\mathrm{NH}_{3}$, or as $\mathrm{N}_{2}$ which could not be detected against the background in atmospheric air. For comparison, gaseous losses of $19-32 \%$ from ${ }^{15} \mathrm{~N}$ labelled urine were indicated in a 406-d field lysimeter experiment with four soil types (Clough et al., 1998).

Nitrous oxide emission rates ranged from ca. $50 \mu \mathrm{g}$ $\mathrm{N}_{2} \mathrm{O}-\mathrm{N} \mathrm{m}^{-2} \mathrm{~h}^{-1}$ in the $C T L$ treatment to a maximum of $350 \mu \mathrm{g} \mathrm{N}_{2} \mathrm{O}-\mathrm{N} \mathrm{m}^{-2} \mathrm{~h}^{-1}$ in $\mathrm{HU}$ by day 9 (Figure 4). This range was similar to, or lower, than initial 

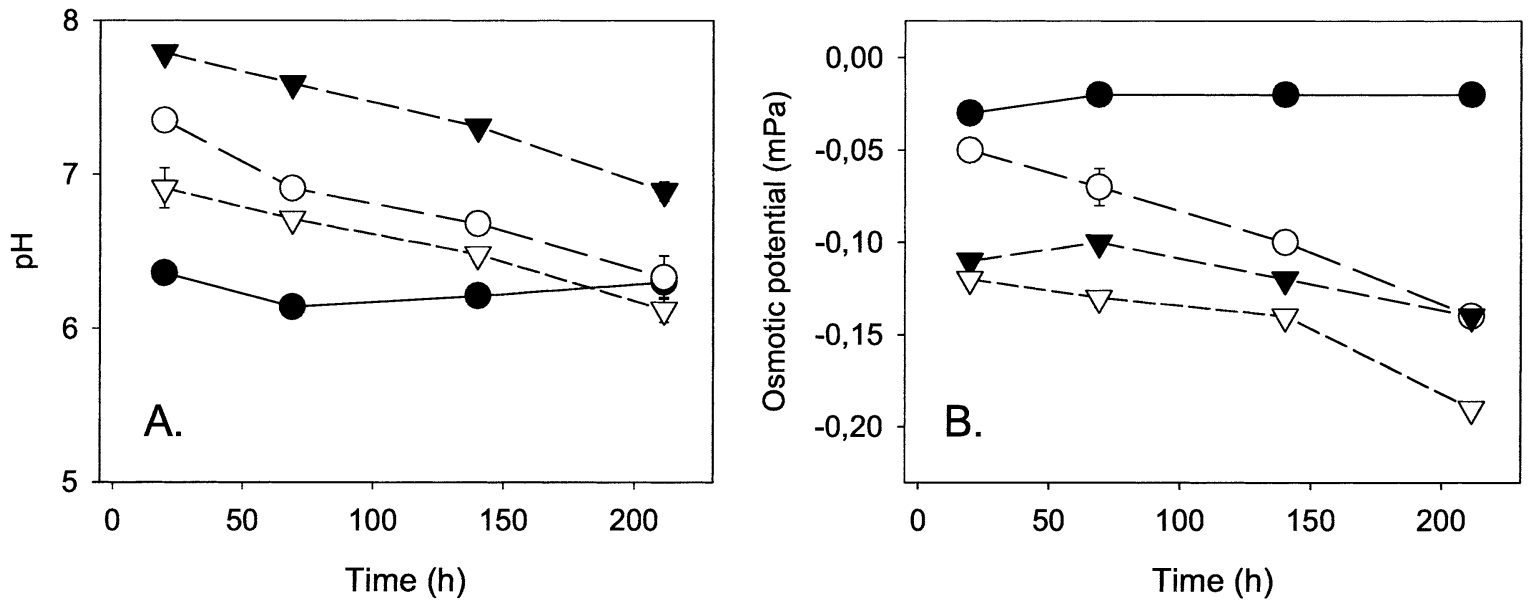

Figure 5. $\mathrm{pH}(\mathrm{A})$ and osmotic potentials $(\mathrm{B})$ in $C T L(\bullet), L U(\circ), H U(\mathbf{\nabla})$ and $L U N(\nabla)$ during the 9-d experiment. Error bars represent standard error $(n=3)$.
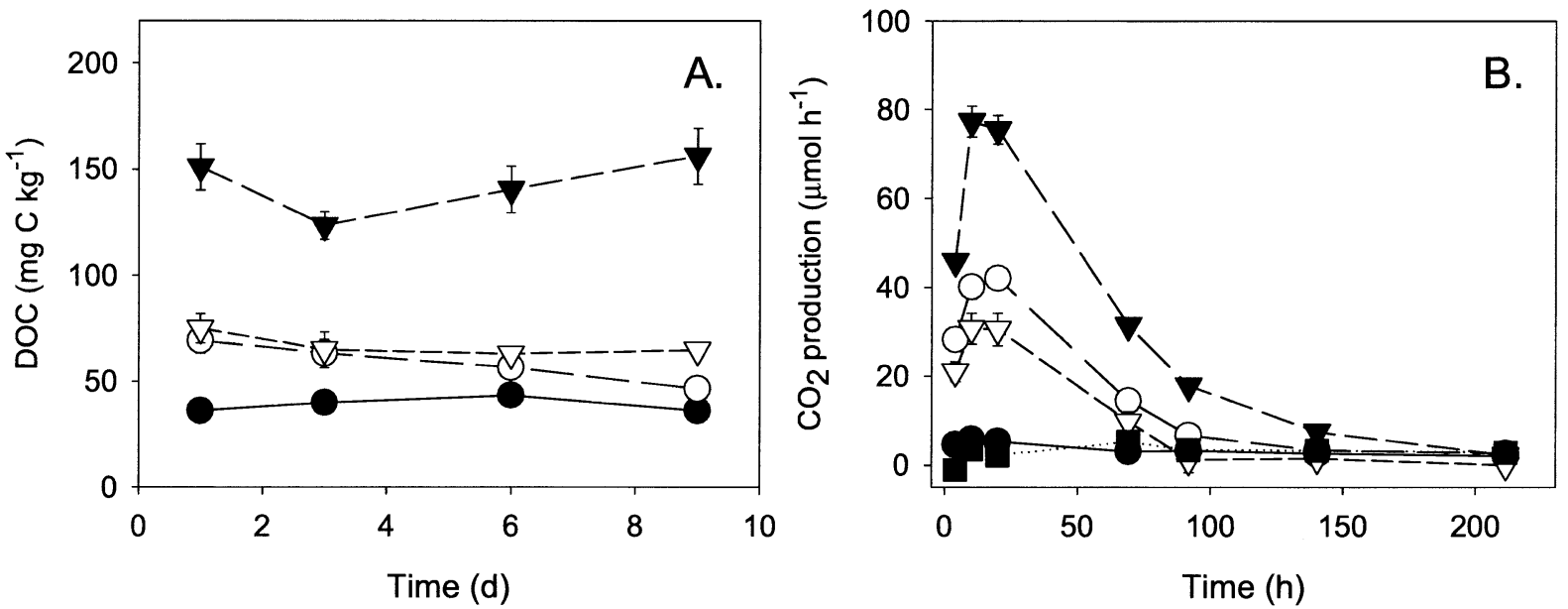

Figure 6. Dissolved organic $\mathrm{C}(\mathrm{A})$ and $\mathrm{CO}_{2}$ evolution rates (B) in $C T L(\bullet), L U(\circ), H U(\boldsymbol{\nabla})$ and $L U N(\nabla)$ during the 9-d experiment. Error bars represent standard error $(n=3)$.

emissions from urine-affected pasture soil observed in other studies (Anger et al., 2003; De Klein et al., 1999; Koops et al., 1997; Lovell and Jarvis, 1996; Yamulki et al., 1998). Emission rates in $H U$ apparently increased beyond the 9-d period of this experiment, in accordance with other studies of $\mathrm{N}_{2} \mathrm{O}$ emission from urine patches where a maximum has been recorded after 2-4 weeks (Allen et al., 1996; Lovell and Jarvis, 1996; Monaghan and Barraclough, 1993). In the present study, accumulated $\mathrm{N}_{2} \mathrm{O}$ emissions during the 9 days represented $0.05-0.1 \%$ of the $\mathrm{N}$ inputs in urea. For comparison, $\mathrm{N}_{2} \mathrm{O}$ emissions equivalent to $0.2-$ $0.3 \%$ of urinary urea- $\mathrm{N}$ were recorded during 7 weeks after deposition of 25.5 or $50.9 \mathrm{~g}$ urea- $\mathrm{N} \mathrm{m}^{-2}$ to monoliths from the pasture where soil for the present experiment was collected (Ambus, 2004).

\section{Effects on nitrification}

Selected soil characteristics were monitored in order to throw light on the potential importance of nitrification and denitrification for the $\mathrm{N}_{2} \mathrm{O}$ emissions observed. Treatment effects on either $\mathrm{pH}$ or osmotic potential were not likely to inhibit $\mathrm{NH}_{4}^{+}$oxidation at the ranges observed (Low et al., 1997; Stark and Firestone, 1995), but the combination of $\mathrm{pH}$ and total ammoniacal nitrogen (TAN) in $H U$ resulted in $\mathrm{NH}_{3}$ (aq) levels in the soil solution of up to $45 \mathrm{mg} \mathrm{L}^{-1}$, as determined by the following modification of the Henderson-Hasselbach equation: 

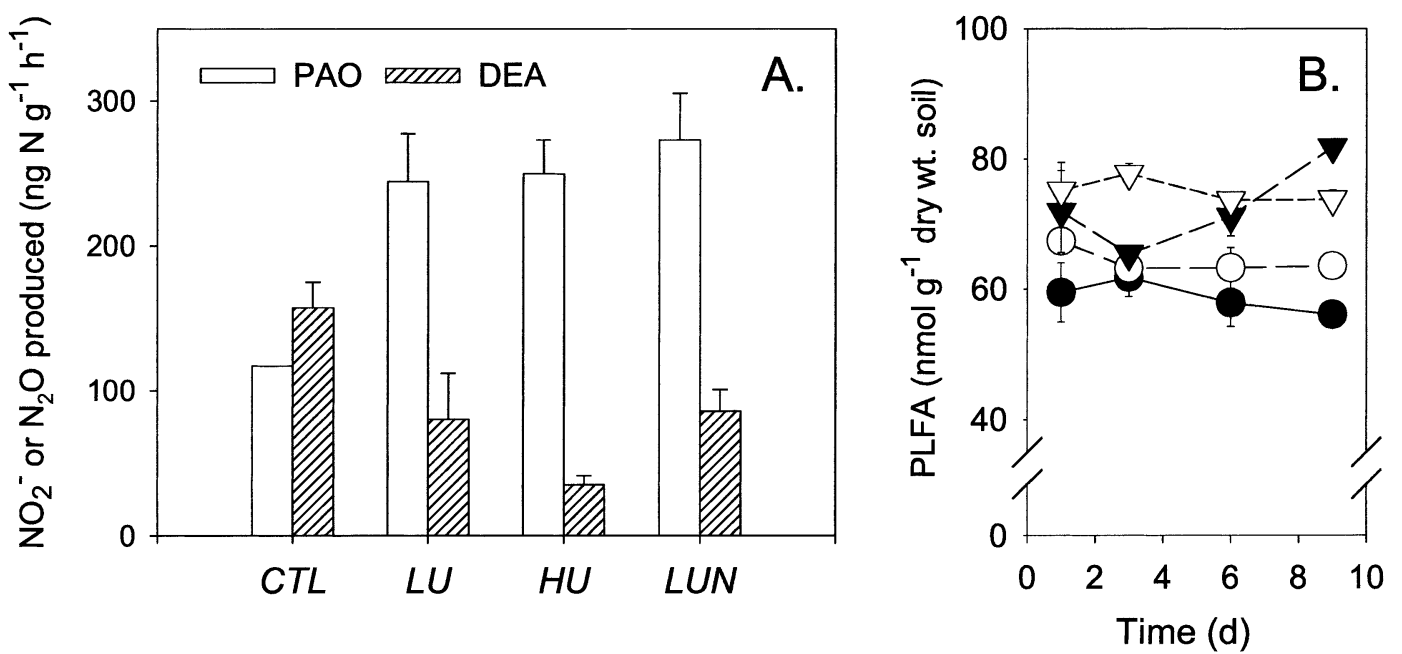

Figure 7. Potential ammonium oxidation (PAO) and denitrifying enzyme activity (DEA) by day 3 (A) and PLFA concentrations (B). Error bars represent standard error $(n=3)$. Key to symbols: $C T L(\bullet), L U(\circ), H U(\nabla), L U N(\nabla)$.

$$
\mathrm{pH}=9.25+\log \left(\left[\mathrm{NH}_{3}\right] /\left[\mathrm{TAN} \div \mathrm{NH}_{3}\right]\right)
$$

where 9.25 is the $\mathrm{pKa}$ of the $\mathrm{NH}_{4}^{+}-\mathrm{NH}_{3}$ equilibrium. According to the relationship described by Monaghan and Barraclough (1992), this level of $\mathrm{NH}_{3}(\mathrm{aq})$ could have given a $>50 \%$ reduction of nitrification rates. In the present experiment, net accumulation of $\mathrm{NO}_{3}^{-}$in $L U, H U$ and $L U N$ after 9 days were 90, 63 and $116 \mathrm{mg}$ $\mathrm{N} \mathrm{kg}^{-1}$, confirming that nitrification was delayed at the higher urea level.

Nitrite oxidation is more readily inhibited than $\mathrm{NH}_{4}^{+}$oxidation (Harada and Kai, 1968), and this may have caused the $\mathrm{NO}_{2}^{-}$accumulation observed in $\mathrm{HU}$ (Figure 2). In this treatment, the $\mathrm{NO}_{2}^{-}$concentration followed a time course similar to $\mathrm{N}_{2} \mathrm{O}$ emissions (cf. Figures 2 and 3). Monaghan and Barraclough (1992) also observed $\mathrm{NO}_{2}^{-}$accumulation at high urineN concentrations, while Stevens et al. (1998) found a direct relationship between $\mathrm{NO}_{2}^{-}$accumulation and $\mathrm{N}_{2} \mathrm{O}$ emissions at $\mathrm{pH} 8$, but not at $\mathrm{pH}$ 5.6-6.5. Nitrous oxide can be produced by nitrifiers via two different pathways (Wrage et al., 2001). It is either derived from hydroxylamine $\left(\mathrm{NH}_{2} \mathrm{OH}\right)$ as a byproduct of $\mathrm{NH}_{4}^{+}$ oxidation, or it is produced via so-called nitrifier denitrification, in which case $\mathrm{NO}_{2}^{-}$is the substrate for a process leading to $\mathrm{N}_{2} \mathrm{O}$ and $\mathrm{N}_{2}$ formation. The correlation of $\mathrm{N}_{2} \mathrm{O}$ emissions and $\mathrm{NO}_{2}^{-}$accumulation in $H U$ was consistent with nitrifier denitrification as a source of $\mathrm{N}_{2} \mathrm{O}$ emissions. While a direct link between the two pools could not be established in this study because ${ }^{15} \mathrm{NO}_{2}^{-}$was not determined, a strong correlation between ${ }^{15} \mathrm{~N}$ labelling of $\mathrm{NO}_{2}^{-}$and $\mathrm{N}_{2} \mathrm{O}$ pools was recently reported for a pasture soil (Müller et al., 2004).

\section{Effects on denitrification}

Denitrification is primarily regulated by (lack of) oxygen, carbon and $\mathrm{NO}_{3}^{-}$availability. Denitrification was not limited by $\mathrm{NO}_{3}^{-}$availability, as indicated by similar $\mathrm{N}_{2} \mathrm{O}$ emissions from $L U$ and $L U N$, and by the absence of $\mathrm{N}_{2} \mathrm{O}$ in the $\mathrm{N}$ treatment $\left({ }^{15} \mathrm{~N}_{2}\right.$ was not detected). Carbon availability could have varied between treatments, since the measurements of DOC indicated that a pool of soil organic matter was dissolved, in accordance with previous observations (e.g., Lovell and Jarvis, 1996). However, the degradability of this DOC appeared to be low, since elevated concentrations were maintained, especially in the $H U$ treatment (Figure 6A), whereas $\mathrm{CO}_{2}$ evolution rates declined to the background level by day 9 (Figure 6B). Also, Kalbitz et al. (2003) studied DOC in grassland soil from a fen area and concluded that only 5-9\% of the dissolved organic matter was labile. We propose that DOC derived from soil organic matter did not significantly stimulate microbial activity in the present experiment, and that $\mathrm{CO}_{2}$ emissions mainly reflected the effect of urea-N on soil microbial turnover.

Emissions of $\mathrm{N}_{2} \mathrm{O}$ via denitrification are often associated with transient conditions such as oxic-anoxic gradients or wetting of a dry soil (Højberg et al., 1994; Rudaz et al., 1991). Sustained $\mathrm{N}_{2} \mathrm{O}$ production via denitrification is mostly associated with low $\mathrm{pH}$ values and/or excess $\mathrm{NO}_{3}^{-}$(Stevens and Laughlin, 1998). In 

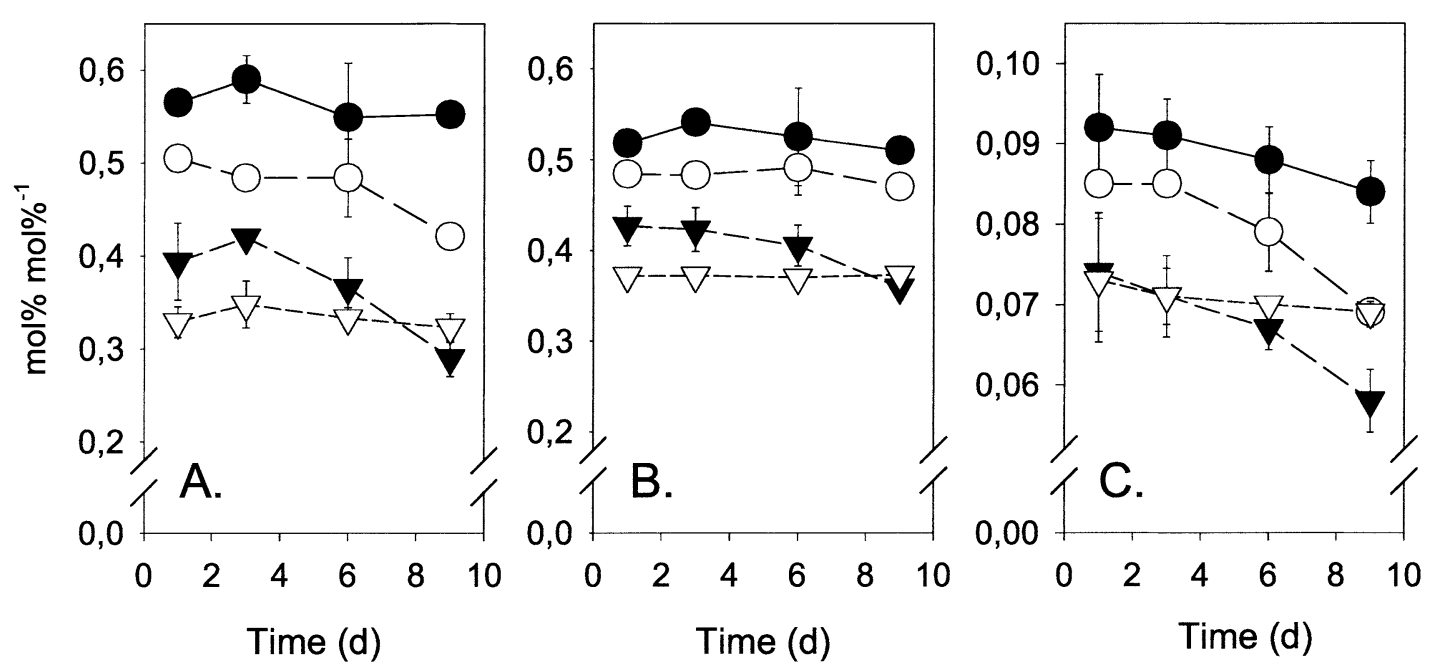

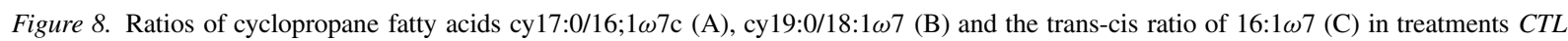
$(\bullet), L U(\circ), H U(\mathbf{\nabla})$ and $L U N(\nabla)$. Error bars represent standard error $(n=3)$.

the present experiment, the $\mathrm{pH}$ in urea-amended soil was higher than in unamended soil, and there was no effect of increasing $\mathrm{NO}_{3}^{-}$availability. Therefore, it appears unlikely that significant amounts of $\mathrm{N}_{2} \mathrm{O}$ were produced via denitrification.

The possibility that $\mathrm{N}_{2} \mathrm{O}$ emissions were partly due to chemodenitrification (references in Nelson, 1982; Venterea and Rolston, 2000) cannot be ruled out. The process is mainly expected to occur under acidic conditions, and in the present study $\mathrm{pH}$ in urea-amended soil was generally above 7 . However, more acidic conditions could have occurred in connection with nitrifying micro-sites.

\section{Microbial dynamics}

DEA was depressed in urea-amended soil by day 3 . Simek et al. (2002) recently showed that DEA is sensitive towards $\mathrm{pH}$ of the soil slurry and often has an optimum near the natural $\mathrm{pH}$ of the soil. The $\mathrm{pH}$ in the slurries of $L U, H U$ and $L U N$ were 6.9-7.2, i.e., higher than the $\mathrm{pH}$ in $C T L$ of 6.3 , and a $\mathrm{pH}$ effect may thus have contributed to the reductions in DEA observed in urea-amended soil. If such a $\mathrm{pH}$ effect was important during the DEA assay, then denitrification activity must have been inhibited in the soil which also had elevated $\mathrm{pH}$ upon urea amendment, especially in $H U$ (Figure 5A) . If, in contrast, a pH effect was not important for the DEA results, then the treatment effects must be interpreted as a decline in the potential for denitrification.
Urea amendment gave comparable stimulations of PAO in $L U, H U$ and $L U N$, but this assay was buffered. An adaptation to ambient soil $\mathrm{pH}$, similar to that observed for DEA, has been described for short-term nitrification activity in pasture soils from various sites in New Zealand (Bramley and White, 1990). This implies that the $\mathrm{pH}$ changes in urea-amended soil could well have affected nitrification activity during incubation in this experiment, as indeed suggested by the dealy in $\mathrm{NO}_{3}^{-}$accumulation in $\mathrm{HU}$ in comparison with $L U$ and $L U N$.

The concentration of PLFA in soil is an index of microbial biomass that is strongly correlated with biomass C (Bailey et al., 2002). Compared to CTL, $H U$ and $L U N$ had elevated concentrations of PLFA even at the first sampling. Microbial dynamics could have been confounded by a shift in lipid extractability or partitioning during extraction at the higher ionic strength in $H U$ and $L U N$ (Frostegård et al., 1991; Nielsen and Petersen, 2000), but subsequent changes in PLFA did not correlate with changes in soil solution properties and were probably dominated by microbial dynamics.

In $H U$, PLFA appeared to decline between day 1 and day 3 but then increased dramatically, especially due to bacterial growth (data not shown). A possible interpretation of this pattern is that initial growth inhibition was transient and replaced by net growth. Active growth between day 3 and day 9 in $H U$ was also indicated by the decline in fatty acid stress indicators (Figure 8). Cyclopropane fatty acids are pro- 
duced in particular by Gram negative bacteria and appear when the organisms enter a stationary phase (Grogan and Cronan, 1997); hence, reduced proportions of these compounds suggest active growth. Elevated trans/cis ratios of membrane lipid fatty acids is another response to environmental stresses observed with some Gram negative bacteria, including Pseudomonas (Heipieper et al., 2003), and so a decline in $16: 1 \omega 7 \mathrm{t} / \mathrm{c}$ may be taken as an indication of stress relief. The observed trends thus imply that any inhibitory effects of urea deposition were replaced by vigorous growth after a few days.

\section{Conclusions}

The microbial response to deposition of urea corresponding to $22-43 \mathrm{~g} \mathrm{~N} \mathrm{~m}^{-2}$ was complex. There was evidence for inhibition of both nitrification and denitrification at the highest urea level, but also an average stimulation of potential ammonium oxidation activity and, after a few days, significant microbial growth. Inhibition and stimulation effects could have been spatially separated, and future work should describe the vertical stratification in more detail. The highest $\mathrm{N}_{2} \mathrm{O}$ emission rates coincided with $\mathrm{NO}_{2}^{-}$accumulation, and nitrifier denitrification is likely to be the main source of $\mathrm{N}_{2} \mathrm{O}$ in this laboratory study. It should be stressed that the well-defined experimental conditions of this study effectively minimized background $\mathrm{N}_{2} \mathrm{O}$ emissions, which are often associated with fluctuating climatic conditions, in order to focus on the direct effects of urea. Also, the exclusion of urine components other than urea reduced $\mathrm{C}$ availability and probably urea turnover rates. Hence, the extent of losses, as well as the balance between nitrification and denitrification in this model system may differ from the field situation. On the other hand, the simplicity of the experimental setup enabled a relatively detailed interpretation of $\mathrm{N}$ dynamics and microbial community changes leading to $\mathrm{N}_{2} \mathrm{O}$ emissions from urea in pasture soil. We conclude that urea concentration in urine deposited on pastures is likely to influence microbial dynamics and soil $\mathrm{N}$ transformations not only quantitatively, but also qualitatively.

\section{Acknowledgement}

This study was supported by the EU Framework Programme 5 project MIDAIR (EVK2 CT-2000-00096), and by the Danish Research Centre for Organic Farming. The technical assistance of M. Astridou is greatly appreciated.

\section{References}

Allen A G, Jarvis S C and Headon D M 1996 Nitrous oxide emissions from soils due to inputs of nitrogen from excreta return by livestock on grazed grassland in the U.K. Soil Biol. Biochem. 28, 597-607.

Ambus P 2004 Short term $\mathrm{N}_{2} \mathrm{O}$ lossses in urine patches: A ${ }^{15} \mathrm{~N}$ labelling study. In Greenhouse gas emissions from agriculture mitigation options and strategies. Ed. A Weiske. pp. 232-233. Int. Conf., Leipzig 12-14 February.

Anger M, Hoffmann C and Kühbauch W 2003 Nitrous oxide emissions from artificial urine patches applied to different $\mathrm{N}$-fertilized swards and estimated annual $\mathrm{N}_{2} \mathrm{O}$ emissions for differently fertilized pastures in an upland location in Germany. Soil Use Manage. 19, 104-111.

Bailey V L, Peacock A D, Smith J L and Bolton Jr. H 2002 Relationships between soil microbial biomass determined by chloroform fumigation-extraction, substrate-induced respiration, and phospholipid fatty acid analysis. Soil Biol. Biochem. 34, 1385-1389.

Belser L W and Mays E L 1980 Specific inhibition of nitrite oxidation by chlorate and its use in assessing nitrification in soils and sediments. Appl. Environ. Microbiol. 39, 505-510.

Bramley R G V and White R E 1990 The variability of nitrifying activity in field soils. Plant Soil 126, 203-208.

Bristow A W, Whitehead D C and Cockburn J E 1992 Nitrogenous constituents in the urine of cattle, sheep and goats. J. Sci. Food Agric. 59, 387-394.

Clough T J, Ledgard S F, Sprosen M S and Kear M J 1998 Fate of ${ }^{15} \mathrm{~N}$ labelled urine on four soil types. Plant Soil 199, 195-203.

De Klein C A M, McTaggart I P, Smith K A, Stevens R J, Harrison R and Laughlin R J 1999 Measurement of nitrous oxide emissions from grassland soil using photo-acoustic infra-red spectroscopy, long-path intra-red spectroscopy, gas chromatography, and continuous flow isotope-ratio mass spectrometry. Comm. Soil Sci. Plant Anal. 30, 1463-1477.

Doran J W, Mielke L N and Stamatiadis S 1988 Microbial activity and nitrogen cycling as regulated by soil water status and bulk density. In Tillage and Traffic in Crop Production. Eds. B D Witney, G Spoor, B D Soane and J T Douglas. pp. 4956. International Soil Tillage Research Organization (11th Intl. Conference), Edinburgh, Scotland.

Frostegård Å and Bååth E 1996 The use of phospholipid fatty acid analysis to estimate bacterial and fungal biomass in soil. Biol. Fertil. Soils 22, 59-65.

Grogan D W and Cronan Jr. J E 1997 Cyclopropane ring formation in membrane lipids of bacteria. Microbiol. Molecul. Biol. Rev. $61,429-441$.

Harada T and Kai H 1968 Studies on the environmental conditions controlling nitrification in soil. Soil Sci. Plant Nutr. 14, 20-26.

Heipieper H J, Meinhardt F and Segura A 2003 The cis-trans isomerase of unsaturated fatty acids in Pseudomonas and Vibrio: biochemistry, molecular biology and physiological function of a unique stress adaptive mechanism. FEMS Microbiol. Lett. 229, $1-7$.

Højberg O, Revsbech N P and Tiedje J M 1994 Denitrification in soil aggregates analyzed with microsensors for nitrous oxide and oxygen. Soil Sci. Soc. Am. J. 58, 1691-1698. 
IPCC 1997 Greenhouse Gas Inventory. Reference Manual. Revised 1996. IPCC Guidelines for National Greenhouse Gas Inventories, Volume 3, London: Intergovernmental Panel on Climate Change.

Kalbitz K, Schmerwitz J Schwesig D and Matzner E 2003 Biodegradation of soil-derived dissolved organic matter as related to its properties. Geoderma 113, 273-291.

Keeney D R and Nelson D W 1982 Nitrogen - Inorganic forms. In Methods of Soil Analysis. part 2. Eds. A L Page et al. pp. 643693. $2^{\text {nd }}$ ed. Agron. Monogr. 9. ASA and SSSA, Madison, WI.

Koops J G, van Beusichem M L and Oenema O 1997 Nitrous oxide production, its source and distribution in urine patches on grassland peat soil. Plant Soil 191, 57-65.

Lindsay W L 1979 Chemical equilibria in soils. J. Wiley \& Sons, New York.

Lovell R D and Jarvis S C 1996 Effects of urine on soil microbial biomass, methanogenesis, nitrification and denitrification in grassland soil. Plant Soil 186, 265-273.

Low A P, Stark J M and Dudley L M 1997 Effects of soil osmotic potential on nitrification, ammonification, $\mathrm{N}$-assimilation, and nitrous oxide production. Soil Sci. 162, 16-27.

Monaghan R M and Barraclough D 1992 Some chemical and physical factors affecting the rate and dynamics of nitrification in urine-affected soil. Plant Soil 143, 11-18.

Monaghan R M and Barraclough D 1993 Nitrous oxide and dinitrogen emissions from urine-affected soil under controlled conditions. Plant Soil 151, 127-138.

Müller C, Stevens R J, Laughlin R J, Ryan M and Jäger H-J 2004 Quantification of $\mathrm{N}$ transformation rates and the mechanisms of $\mathrm{N}_{2} \mathrm{O}$ production and emission in an old grassland soil. In Greenhouse gas emissions from agriculture - mitigation options and strategies. Ed. A Weiske. pp. 79-84. Int. Conf., Leipzig 12-14 February.

Nason G E and Myrold D D $1991{ }^{15} \mathrm{~N}$ in soil research: Appropriate application of rate estimation procedures. Agric. Ecosys. Environ. 34, 427-441.

Nelson D W 1982 Gaseous losses of nitrogen other than through denitrification. In Nitrogen in Agricultural Soils. Eds. F J Stevenson et al. pp. 327-363. Agron. Monogr. No. 22, American Society for Agronomy, Madison, WI.

Nielsen P and Petersen S O 2000. Ester-linked polar lipid fatty acid profiles of soil microbial communities: A comparison of extraction methods and evaluation of interference from humic acids. Soil Biol. Biochem. 32, 1241-1249.

Oenema O, Velthof G L, Yamulki S and Jarvis S C 1997 Nitrous oxide emissions from grazed grassland. Soil Use Manage. 13, 288-295.

Petersen S O, Frohne P S and Kennedy A C 2002 Dynamics of a soil microbial community under spring wheat. Soil Sci. Soc. Am. J. 66, 826-833.

Petersen S O, Sommer S G, Aaes O and Søegaard K 1998 Ammonia losses from urine and dung of grazing cattle: Effect of $\mathrm{N}$ intake. Atmos. Environ. 32, 295-300.

Rawlins S L and Campbell G S 1986 Water potential: Thermocouple psychrometry. In Methods of Soil Analysis. Part 1. Physical and Mineralogical Methods. Ed. A Klute. pp. 597-618. $2^{\text {nd }}$ ed, Am. Soc. Agron., Madison, WI.
Richards I R and Wolton K M 1975 A note on urince scorch caused by grazing animals. J. Br. Grassland. Soc. 30, 187-188.

Rudaz A O, Davidson E A and Firestone M K 1991 Sources of nitrous oxide production following wetting of dry soil. FEMS Microbiol. Ecol. 85, 117-124.

Schepers J S, Francis D D and Thompson M T 1989 Simultaneous determination of total $\mathrm{C}$, total $\mathrm{N}$, and ${ }^{15} \mathrm{~N}$ on soil and plant material. Commun. Soil Sci. Plant Anal. 20, 949-959.

Sherlock R R and Goh K M 1984. Dynamics of ammonia volatilization from simulated urine patches and aqueous urea applied to pasture. I. Field experiments. Fertil. Res. 5, 181-195.

Simek M, Jisova L and Hopkins D W 2002 What is the so-called optimum $\mathrm{pH}$ for denitrification in soil? Soil Biol. Biochem. 34, 1227-1234.

Smith J L and Doran J W 1996 Measurement and use of pH and electrical conductivity for soil quality analysis. In Methods for Assessing Soil Quality. Eds. J W Doran and A J Jones. pp. 169_ 185. Soil Science Society of America Special Publication No. 49. Madison, WI.

Somda Z C, Powell J M and Bationo A 1997 Soil pH and nitrogen changes following cattle and sheep urine deposition. Comm. Soil Sci. Plant Anal. 28, 1253-1268.

Stark J M and Firestone M K 1995 Mechanisms for soil moisture effects on activity of nitrifying bacteria. Appl. Environ. Microbiol. 61, 218-221.

Stevens R J and Laughlin R J 1998 Measurement of nitrous oxide and di-nitrogen emissions from agricultural soils. Nutr. Cycl. Agroecosys. 52, 131-139.

Stevens R J, Laughlin R J and Malone J P 1998 Soil pH affects the processes reducing nitrate to nitrous oxide and di-nitrogen. Soil Biol. Biochem. 30, 1119-1126.

Sørensen P and Jensen E S 1991 Sequential diffusion of ammonium and nitrate from soil extracts to a polytetrafluoroethylene trap for ${ }^{15} \mathrm{~N}$ determination. Anal. Chim. Acta 252, 201-203.

Tiedje J M, Simkins S and Groffman PM 1989 Perspectives on measurement of denitrification in the field including recommended protocols for acetylene based methods. In Ecology of Arable Land. Eds. M Clarholm and L Bergström. pp. 217-240. Klüwer Acaddemic Press, Dordrecht.

Vance E D, Brookes P C and Jenkinson D S 1987 An extraction method for measuring soil microbial biomass. Soil Biol. Biochem. 19, 703-707.

Venterea R T and Rolston D E 2000 Mechanistic modeling of nitrite accumulation and nitrogen oxide gas emissions during nitrification. J. Environ. Qual. 29, 1741-1751.

Whitehead D C, Lockyer D R and Raistrick N 1989 Volatilization of ammonia from urea applied to soil: Influence of hippuric acid and other constituents of livestock urine. Soil Biol. Biochem. 21, 803-808.

Wrage N, Velthof G L, van Beusichem M L and Oenema O 2001 Role of nitrifier denitrification in the production of nitrous oxide. Soil Biol. Biochem. 33, 1723-1732.

Yamulki S, Jarvis S C and Owen P 1998 Nitrous oxide emissions from excreta applied in a simulated grazing pattern. Soil Biol. Biochem. 30, 491-500. 